\title{
Histological changes in the gills, livers and muscles of Oreochromis niloticus fed with steriod, natural hormone and pawpaw seed based diets
}

\author{
Ekinadose Orose ${ }^{1}$ • Okechukwu Kenneth Wokeh ${ }^{2}$ - Edafe Odioko ${ }^{3 *}$ \\ 1 Department of Animal and Environmental Biology, Faculty of Science, University of Port Harcourt, \\ PMB 5323 Choba, Port Harcourt, Rivers State, Nigeria \\ 2 Department of Animal and Environmental Biology, Faculty of Science, University of Port Harcourt, \\ PMB 5323 Choba, Port Harcourt, Rivers State, Nigeria \\ ${ }^{3}$ Department of Fisheries Engineering, Faculty of Fisheries, Akdeniz University, 07070 Konyaaltı, Antalya, Turkey
}

(D) https://orcid.org/0000-0002-4064-8042

(D) https://orcid.org/0000-0002-3963-5682

https://orcid.org/0000-0001-7562-4203

\section{How to cite this paper:}

Orose, E., Wokeh, O. K. \& Odioko, E. (2021). Histological changes in the gills, livers and muscles of Oreochromis niloticus fed with steriod, natural hormone and pawpaw seed based diets. Ege Journal of Fisheries and Aquatic Sciences, 38(4), 487-497. DOI: 10.12714/egejfas.38.4.10

Abstract: This study was conducted to evaluate the histological changes of 17 amethyl-testosterone (MT), wet testes of bull (Bos indicus), boar (Sus domesticus), bull/mud catfish testes (B. indicus/C. gariepinus) and pawpaw (Carica papaya) seed powder-based diet on the Nile tilapia fry in an indoor experimental pond. Histological changes and efficacies in producing monosex males were determined after four months. Fifty-five fry were assigned randomly to three experimental ponds in triplicates. Five experimental feeds composed of soya-bean, fish meal, wheat bran, cassava flour were formulated by adding $0.06 \mathrm{~g}$ of $17 \mathrm{a}$ - methyl-testosterone, $17.47 \mathrm{~g}$ of bull wet testes, $25.59 \mathrm{~g}$ of boar wet testes, $20.48 \mathrm{~g}$ of bull/catfish and $20 \mathrm{~g}$ of pawpaw seed powder per $\mathrm{kg}$ of feed to group 1, 2, 3, 4, 5 respectively. Obtained results from the morphological examination revealed a significant difference $(p<0.05)$ in phenotypic males of the Nile tilapia fry fed with the experimental diets. The highest indistinct percentage was recorded in the 17 amethyl-testosterone-treated diet while the lowest was recorded in diets 3 and 4 with no significant differences. All the groups showed histopathological differences in the livers, gills, and muscles. However, the liver histology of groups 1 and 5 showed central vessels that are mildly congested with abundant glycogen vacuolation and somewhat fat infiltration, while the histology of the muscles of group 5 showed pathological lesions including moderate to severe necrosis. These alterations can be considered an indication of the performance and health of fish in monosex culture medium indicating effects of plant extract and MT.

Keywords: Histological changes, Oreochromis niloticus, monosex, 17a- methyl-testosterone, pawpaw seed

\section{INTRODUCTION}

Overstocking of tilapia in an enclosed pond causes stunted growth due to the unavailability of natural food, especially in the semi-intensive system (Meske and Vogt, 2014). To achieve more productivity in growing tilapia Oreochromis niloticus, it is important to produce a monosex culture that constitutes males (El-Greisy and El-Gamal, 2012), because male grows faster than female because of unnecessary spawning. The most efficient method of producing only males is using steroid hormones fed to newly hatched fry with unknown sex (Ajiboye et al., 2015). This is done by exposing the fish to hormones (testosterone or estrogen) in their diets orally for several weeks when the fish start feeding, which leads to sex reversal. The application of synthetic hormones is under serious criticism due to their health and environmental hazards. More so, there is little literature on the tangible effect of the residuals on the environment and human health (Desprez et al., 2003, Mengumphan et al., 2006).

Thus far, the caused by the synthetic hormone on environmental damage or harm to humans used for sex inversion has no substantial proof; however, there is a huge amount of MT used for sex reversal compared to the actual dose (Xu et al., 2015; Mlalila et al., 2015), which may lead to building up of MT chemical in tilapia farming. Hormone treated fish is restricted in some countries except it is proven that it will not pose risks to human health (Megbowon and Mojekwu, 2014). However, the potential disadvantage of synthetic hormone treatment increased the risk of long-term exposure of workers handling methyltestosterone during food preparation and feeding may cause adverse effects on their health (Green et al., 1997). There have been reports that hormones excreted by treated fish from undigested feeds can build up in a closed water system; accumulate in water residue and aquatic biota (Dauda et al., 2014). Kefi et al. (2013) in their trial with tilapia fish, observed an induced sex inversion in waters not directly applied with methyltestosterone, although is not well understood; the effect on water pollution.

Owing to the detrimental toxicity of hormone on human health which results in mostly carcinogenic and endocrine disorder and on the environment, researchers has deliberated on its use in aquaculture production (Dergal et al., 2016). Furthermore, the use of anabolic steroids has been banned because of the harmfulness to humans, fish and the environment (Suseno et al., 2020); based on the decision from the Republic of Indonesia with number KEP.52/MEN/2014 of the Ministry of Marine Affairs and Fisheries. 
In recent times, the use of MT in the seed production of Oreochromis species has increased despite inadequate information about the impact of the androgen on fish physiology; though, its long-term impacts on the pathology of livers, gills and muscle remain unclear (Kefi et al., 2013). Curtis et al. (1991) established the fact that metabolizes of plasma testosterone are quickly excreted from the body. There are few published articles on the histological changes of 0 . niloticus subjected to sex steroids in particular MT, animal, and plant extract; hence, the need to evaluate the histological changes associated with the gills, livers, and muscles of 0 . niloticus subjected to MT, animal hormone and plant extract. Therefore, this study will help to understand the effects of 0 . niloticus exposed to the different sex reversalsbased diets and provide fishery resources managers and decision-makers information on the most fish-friendly and effective sex reversal-based diet.

\section{MATERIAL AND METHODS}

A total of 825 Oreochromis niloticus (Nile tilapia) fry with an average weight of $0.013 \mathrm{~g}$; were obtained from the Tilapia family testing unit of the Africa Regional Aquacultural Center (ARAC) Aluu, Port Harcourt, Rivers State. The experiment was carried out in 15 different experimental ponds at ARAC and was distributed randomly into five groups; fifty-five (55) fry were stocked in each in triplicate. The methyl-testosterone was acquired from Lagos State (University of Lagos) Nigeria while the testes of boar bull fish were procured from Port Harcourt market, while pawpaw fruits were collected from the University of Port Harcourt Farm which was sun-dried, ground and prepared as described by (Orose et al., 2016).

\section{Hormone preparation}

The hormone was prepared by adding $0.06 \mathrm{~g}$ of $17 \mathrm{a}$ Methyltestosterone, $4 \mathrm{~g}$ of catfish testes, $10 \mathrm{~g}$ of boar and bull testes to a beaker containing $500 \mathrm{ml}$ of ethanol (95\%) respectively, while $5.7 \mathrm{~g}$ of pawpaw seed powder was dissolved in water for hormonal analysis (testosterone/estrogen) at the Chemical Pathology Laboratory, University of Port Harcourt Teaching Hospital (UPTH) for hormonal analysis. Total testosterones from the serum of each experimental animal were analyzed using an Enzyme Immunoassay Testosterone test kit (Table 1). The $1000 \mathrm{~g}$ compounded feed was formulated with the addition of the steroid hormone and plant extract. Group 1 was added with $0.06 \mathrm{~g}$ of $17 \mathrm{a}$ - methyl-testosterone, group 2 was prepared with $17.47 \mathrm{~g}$ of bull testes, group 3 was prepared with $25.59 \mathrm{~g}$ of boar testes, group 4 was prepared by adding $20.48 \mathrm{~g}$ of bull/ catfish testes while group 5 was prepared by adding $20 \mathrm{~g}$ of pawpaw seed powder-based diet (Orose et al., 2018).

\section{Exposure of test organisms}

One thousand grams of feed was formulated based on the working composition obtained from the feed mill of ARAC, using $40 \%$ crude protein. The formulated feed materials were composed of wheat bran, fish meal soya-bean, groundnut cake, vitamins etc. in various percentages as described by Orose and Vincent-Akpu, 2016. The feeding frequency was three times daily at $20 \%$ of fish body weight for 42 days hormonal trial with final weight for group $0.42 \mathrm{~g}, 0.52 \mathrm{~g}, 0.78 \mathrm{~g}$, $0.60 \mathrm{~g}$ and $0.69 \mathrm{~g}$ for group 1 to 5 respectively. Thereafter, the fry were reared for 4 months for histological studies with final weights of $7.30 \mathrm{~g}, 10.43 \mathrm{~g}, 11.73 \mathrm{~g}, 10.67 \mathrm{~g}$ and $10.40 \mathrm{~g}$ for groups 1 to 5 respectively.

Table 1. Total testosterone of steroid, animal and pawpaw seed powder

\begin{tabular}{lcc}
\hline \multicolumn{1}{c}{ Treatments } & Sample (gram) & Concentration \\
\hline Treatment 1 (MT) & $0.06 \mathrm{~g}$ & 16.25 \\
Treatment 2 (bull testes) & $10 \mathrm{~g}$ & 9.3 \\
Treatment 3 (boar testes) & $10 \mathrm{~g}$ & 6.3 \\
Treatment 4 (catfish testes) & $4 \mathrm{~g}$ & 1.8 \\
Treatment 5 (PSP) & $5.7 \mathrm{~g}$ & 0.3 \\
\hline
\end{tabular}

\section{Sex determination}

After four months of growth stage, sexing of fingerlings was determined, each group was collected in all the replicates and confirmed by examining the external genitals (Figure 1).

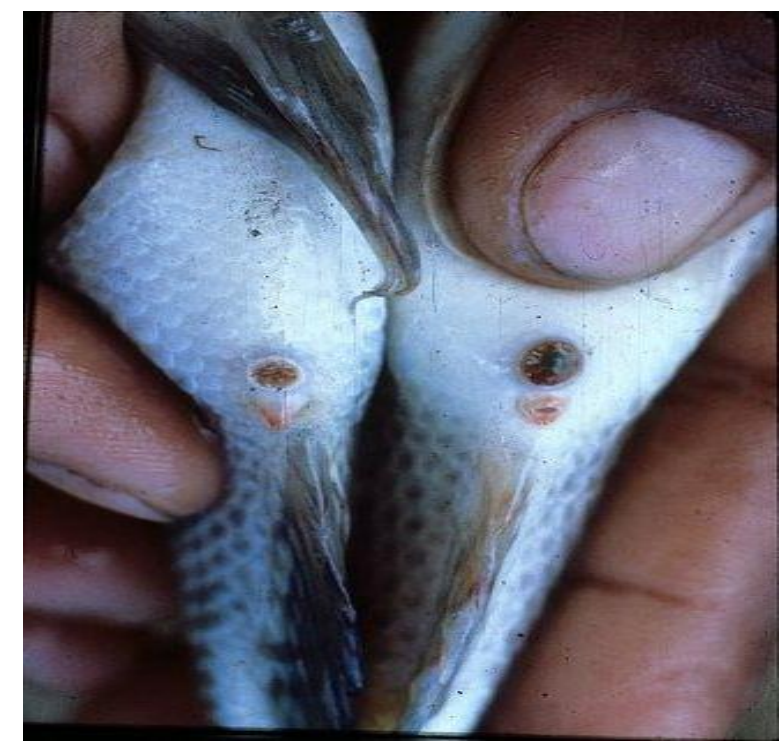

Figure 1. Male (left) and female (right) genital papilla (Fuentes Silva et al., 2013)

\section{Histological Changes}

Fish samples were prepared with standard methods for histological analysis as detailed in the guideline as describe by Avwioro, (2010). Livers, gills, and muscles of 5 fish per treatment were surgically removed and placed in $10 \%$ Davison's solution and taken to the Veterinary Department of the Federal University of Agriculture, Abeokuta. The livers gills and muscles were fixed and prepared for sectioning involved dehydration, clearing and infiltration, embedding and sectioning using a microtome. The process for dehydration involved fixation of tissue in ascending grades alcohol of $30 \%$, $50 \% 70 \%$ and $90 \%$ alcohol each for 1 hour; $95 \%$ alcohol for 12 hours; and absolute alcohol for 1 hour. The clearing 
process involved immersion of dehydrated tissue in xylene for 1 hour. The infiltration process involved immersion of the cleared samples in molten paraffin wax (between $56^{\circ} \mathrm{C}-$ $60^{\circ} \mathrm{C}$ ) for two hours. The embedded tissues were sectioned using a microtome before placing them on slides then staining with Haematoxylin for 3 minutes and 1\% solution of Eosin stain for 5-10minutes ( $H$ and $E$ method). The prepared slides were viewed under a light microscope, Olympus CX31RTSF.

\section{Data Analysis}

All data were subjected to statistical analysis using Statistical Package for Social Sciences (SPSS) version 21, analysis of variance (ANOVA) was used to determine significant differences among treatments. Differences were regarded as significant at $P<0.05$; mean significant was compared using Duncan Multiple Range Test (DMRT).

\section{RESULTS}

Effect of experimental diet on masculinization of Nile Tilapia (0. niloticus)

The results for the morphological examination on sex ratio are presented in Table 2. There was no significant difference between group 3 and group 4 , although there were significant differences ( $p<0.05)$ among group 1 , group 2 and group 5 . The lowest male value was observed in group 5
$(73.98 \pm 2.04 \%)$. The results on indistinct (sex differentiation that was not clear) showed that group 1 had a higher indistinct $(5.00 \pm 0.58)$, while there was no significant difference $(p \geq 0.05)$ between group 3 and group 4 .

Effect of experimental diets on mortality rate of Nile Tilapia (0. niloticus)

The result on the mortality rate of Nile tilapia fries after the four months experimental period is shown in Figure 2. The result showed that group 1 recorded the highest mortality $(51 \%)$ during the experiment, followed by group $2(18 \%)$. However, there were no significant differences in mortality rates among group 3, group 4 and group 5 with mortality rates of $10 \%, 11 \%$, and $10 \%$ respectively.



Figure 2. Mortality rate of Nile tilapia fed five experimental diets ( 5 groups)

Table 2. Morphological effect of treatments on sex ratio of O niloticus

\begin{tabular}{|c|c|c|c|c|c|}
\hline \multicolumn{6}{|c|}{ Numbers of Fish Observed per Group (percentages are in parentheses) } \\
\hline Sex & 1 & 2 & 3 & 4 & 5 \\
\hline Male & $\begin{array}{c}19.00 \pm 1.53^{\mathrm{c}} \\
\left(79.17 \pm 0.74^{\mathrm{bc}}\right)\end{array}$ & $\begin{array}{c}30.33 \pm 2.00^{b} \\
\left(79.82 \pm 1.03^{b}\right)\end{array}$ & $\begin{array}{c}37.67 \pm 1.20^{\mathrm{a}} \\
\left(91.88 \pm 2.11^{\mathrm{a}}\right)\end{array}$ & $\begin{array}{c}36.67 \pm 0.88^{a} \\
\left(91.68 \pm 0.59^{a}\right)\end{array}$ & $\begin{array}{c}30.33 \pm 0.88^{b} \\
\left(73.98 \pm 2.04^{b}\right)\end{array}$ \\
\hline Female & $\begin{array}{l}0.00 \pm 0.00^{d} \\
\left.0.00 \pm 0.00^{d}\right)\end{array}$ & $\begin{array}{c}3.67 \pm 0.33^{b} \\
\left.9.66 \pm 0.27^{b}\right)\end{array}$ & $\begin{array}{l}2.67 \pm 0.33^{c} \\
6.51 \pm 0.68 c)\end{array}$ & $\begin{array}{l}3.00 \pm 0.00^{b c} \\
\left.7.50 \pm 0.60^{c}\right)\end{array}$ & $\begin{array}{c}7.33 \pm 0.33^{a} \\
\left.17.88 \pm 0.60^{a}\right)\end{array}$ \\
\hline Indistinct & $\begin{array}{c}5.00 \pm 0.58^{a} \\
\left.20.83 \pm 0.74^{a}\right)\end{array}$ & $\begin{array}{c}4.00 \pm 1.00^{a} \\
10.52 \pm 1.98^{b}\end{array}$ & $\begin{array}{l}0.67 \pm 0.67^{b} \\
\left.1.61 \pm 1.63^{c}\right)\end{array}$ & $\begin{array}{l}0.33 \pm 0.21^{b} \\
\left.0.82 \pm 0.80^{c}\right)\end{array}$ & $\begin{array}{l}3.34 \pm 0.88^{a} \\
\left.8.14 \pm 2.05^{d}\right)\end{array}$ \\
\hline Total & $\begin{array}{c}24 \\
(100)\end{array}$ & $\begin{array}{c}38 \\
(100)\end{array}$ & $\begin{array}{c}41 \\
(100)\end{array}$ & $\begin{array}{c}41 \\
(100)\end{array}$ & $\begin{array}{c}41 \\
(100)\end{array}$ \\
\hline
\end{tabular}

$a, b, c$ and $d$ are superscripts to indicate significant differences among different groups/ Mean values (mean \pm standard error) in the same row with different superscript are significantly different $(p<0.05)$.

\section{Histological examination}

Histological changes in the livers of Oreochromis niloticus fed experimental diets

The histological analysis of the livers revealed that there were pathological differences among the groups. Group 1 photomicrograph of fish liver showed Central vessels that are mildly congested with mildly thickened vascular wall (white arrow), the sinusoids (black arrow) appear normal and not infiltrated by inflammatory cells while the hepatocytes showed abundant glycogen vacuolation and somewhat fat infiltration (blue arrow) (Figure 3), Group 2 showed section with normal central vessels that are not congested (white arrow), however, there was mild perivascular infiltration seen (gray arrow), the sinusoids (black arrow) appeared normal and not infiltrated by inflammatory cells, the hepatocytes showed abundant glycogen vacuolation (blue arrow) (Figure 4), group 3 showed normal central vessels that are not congested (white arrow), the sinusoids (black arrow) appeared normal and not infiltrated by inflammatory cells, the hepatocytes showed moderate glycogen vacuolation (blue arrow) (Figure 5), additionally, group 4 showed normal central vessels that are not congested (white arrow), the sinusoids (black arrow) appeared normal and not infiltrated by inflammatory cells, the hepatocytes showed abundant glycogen vacuolation (blue arrow) Figure 6 . On the other hand, group 5 showed mildly congested central vessels (white arrow), the sinusoids (black arrow) appeared normal and not infiltrated by inflammatory 
cells, the hepatocytes showed abundant glycogen vacuolation and fat degeneration (blue arrow) (Figure 7). However, there appeared to be differences in their hepatocytes: group 1 showed abundant glycogen vacuolation and somewhat fat infiltration, group 2 and 4 showed abundant glycogen vacuolation, group 3 showed moderate glycogen vacuolation while group 5 showed abundant glycogen vacuolation with fat degeneration.


Figure 3. Photomicrograph of group 1 fish liver section
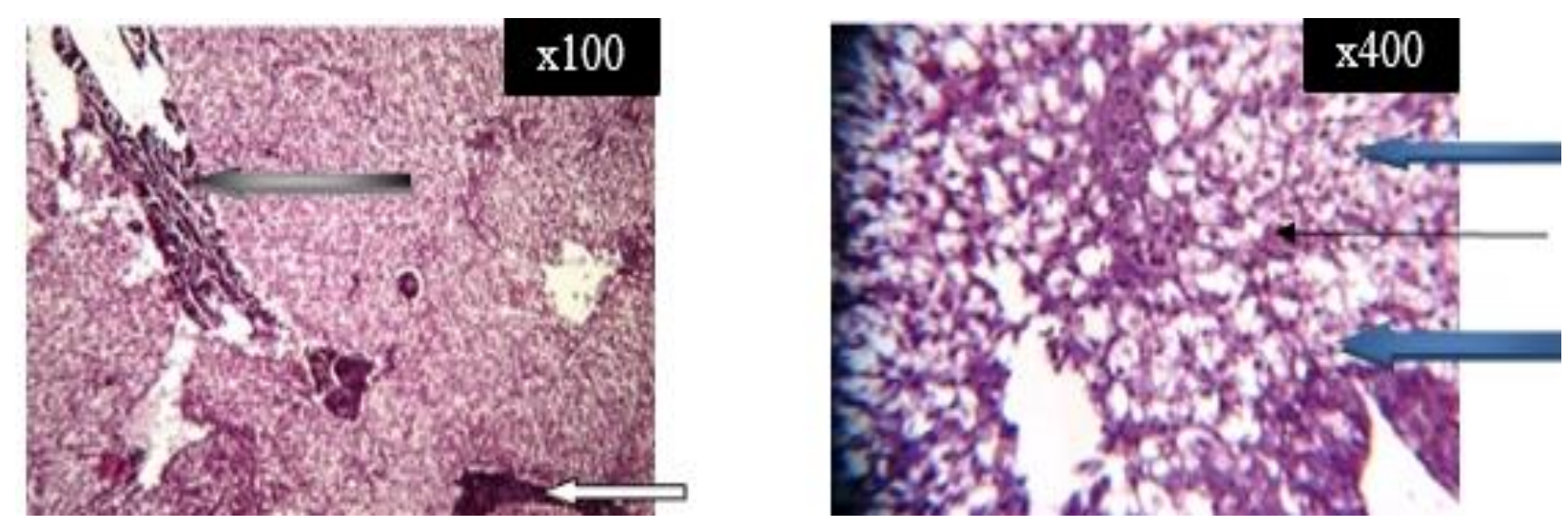

Figure 4. Photomicrograph of group 2 fish liver section
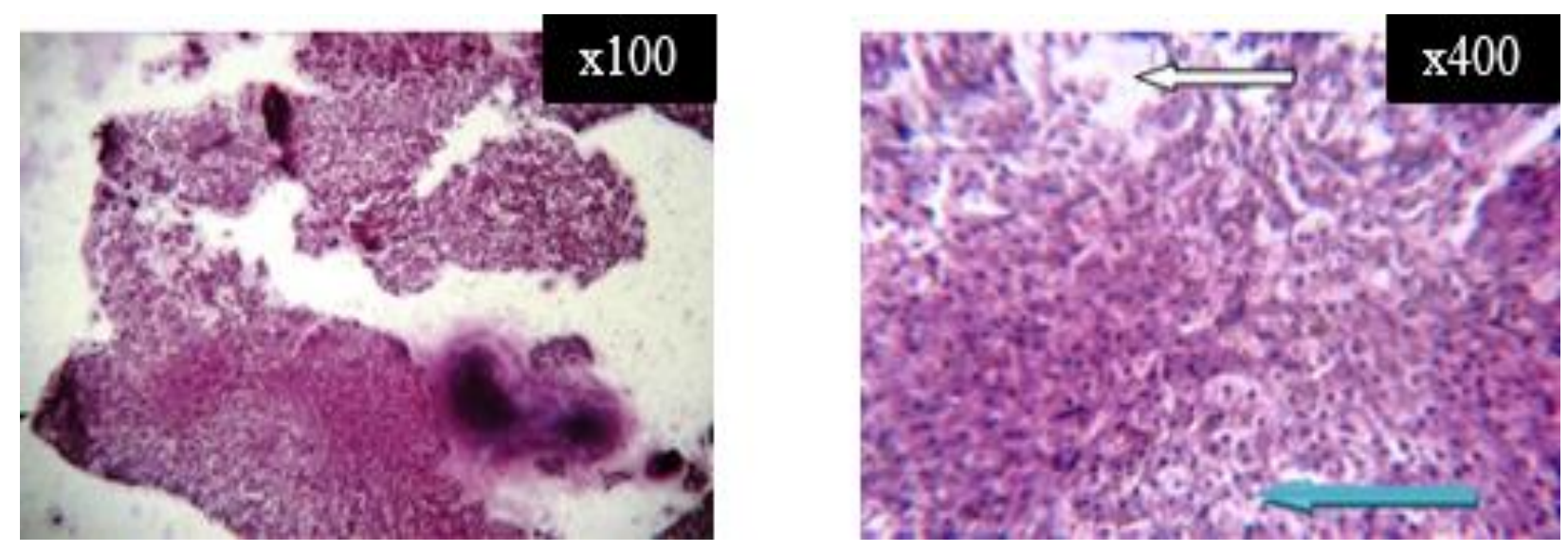

Figure 5. Photomicrograph of group 3 fish liver section 


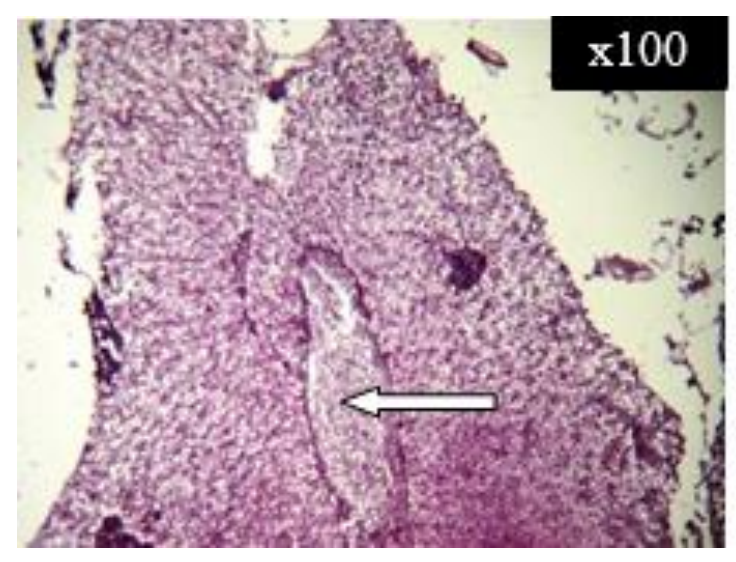

Figure 6. Photomicrograph of group 4 fish liver section

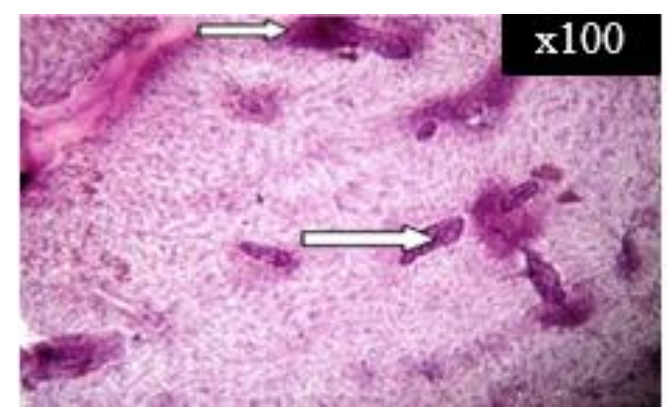

Figure 7. Photomicrograph of group 5 fish liver section

\section{Histological changes in the gills of Oreochromis niloticus fed experimental diets}

The histopathological study of the gills section revealed that the gills section for group 1 showed normal gill lamellae (white arrow) and arch (blue arrow) lamellae consist of normal erythrocytes, chloride cells and pillar cells (black arrow), while the gill arch showed normal osteocyte-like cells (Figure 8). Group 2 had a normal gill lamella (white arrow) and arch (blue arrow) the lamellae consist of normal erythrocytes, chloride cells and pillar cells (black arrow) while the gill arch showed


normal osteocyte-like cells (Figure 9). Group 3 showed poorly arranged gill lamellae (white arrow) and arch (blue arrow). The lamella consists of normal chloride cells and pillar cells (black arrow), while the gill arch showed normal osteocyte-like cells (Figure 10). Group 4 showed shortened gill lamellae (white arrow) and arch the lamellae consisting of normal erythrocytes and few chloride cells and pillar cells (Figure 11), while group 5 showed normal gill lamellae (white arrow) and arch (blue arrow) (Figure 12). The lamellae consist of normal erythrocytes, chloride cells and pillar cells (black arrow), while the gill arch showed normal osteocyte-like cells.
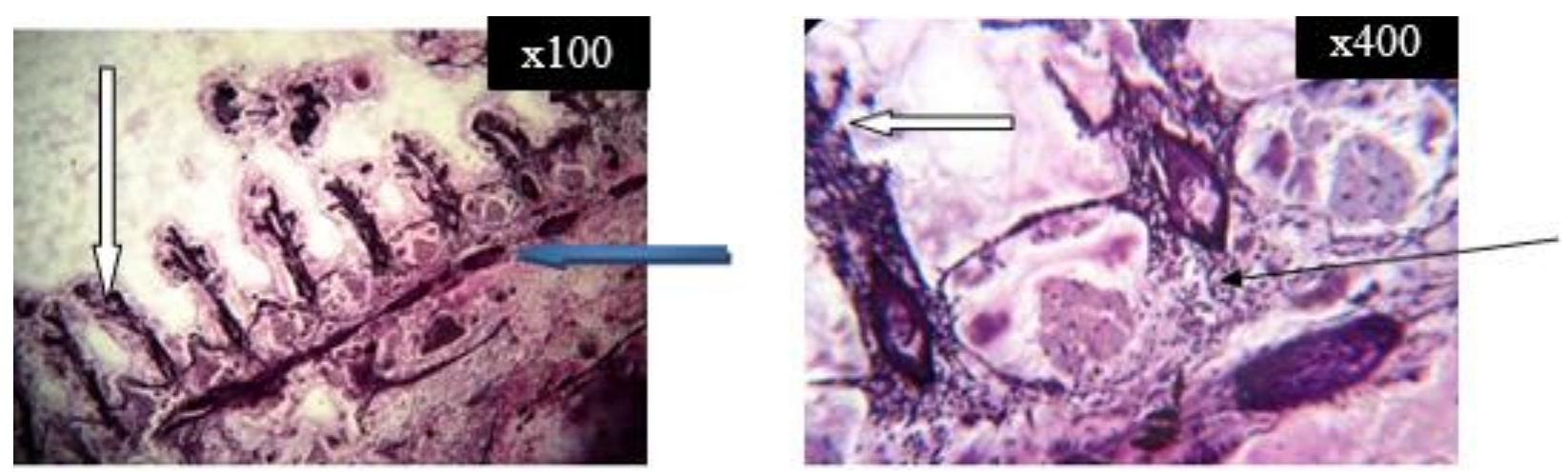

Figure 8. Photomicrograph of group 1 fish gill section 

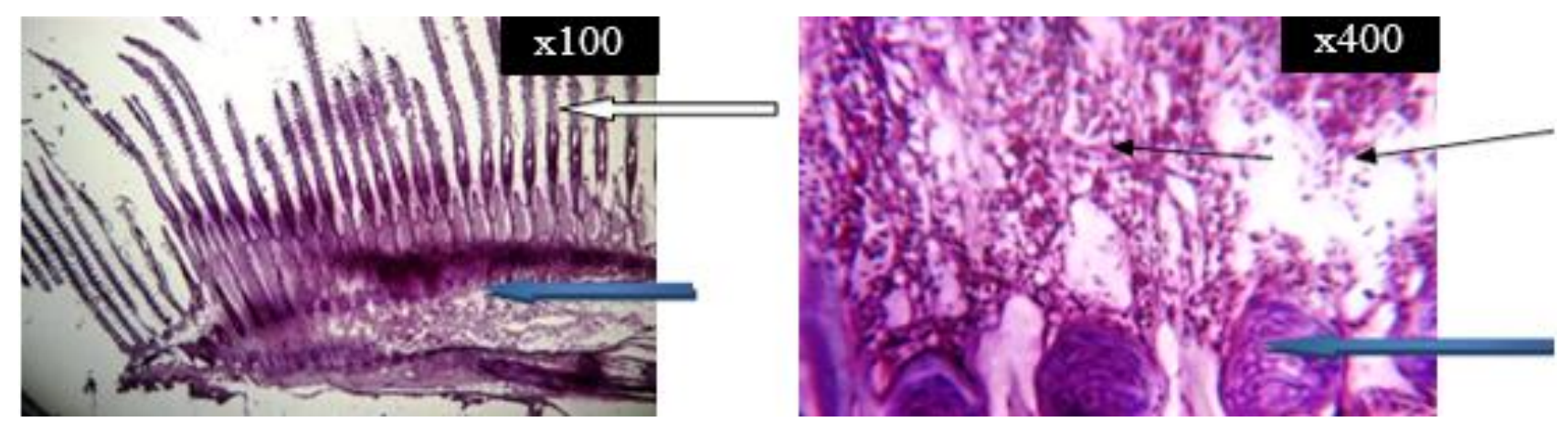

Figure 9. Photomicrograph of group 2 fish gill section
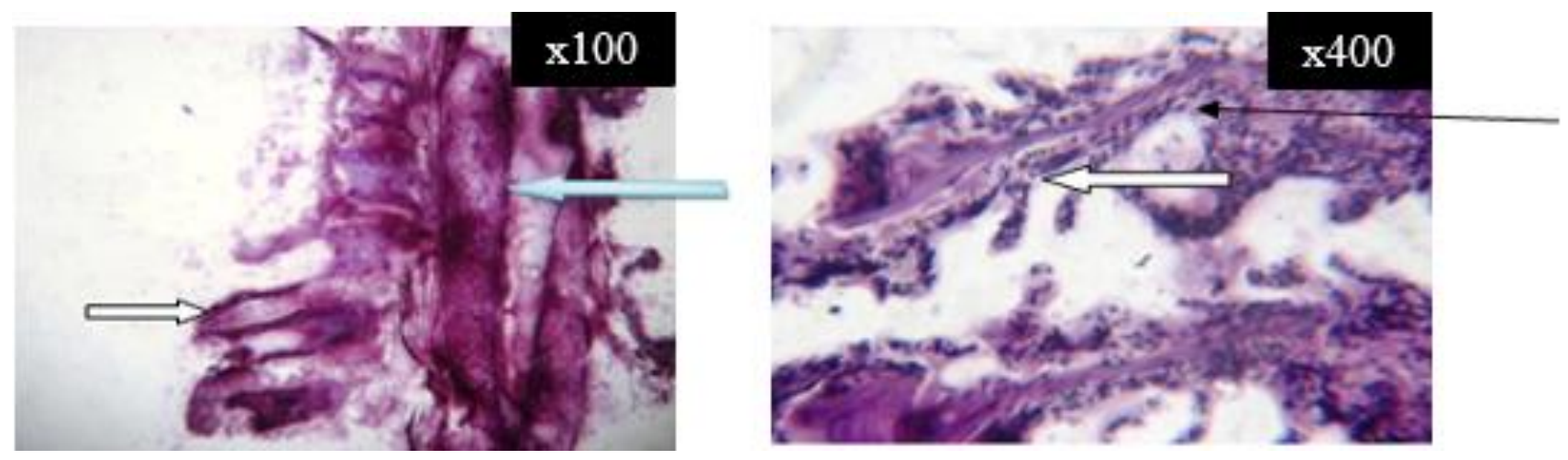

Figure 10. Photomicrograph of group 3 fish gill section


Figure 11.Photomicrograph of group 4 fish gill section
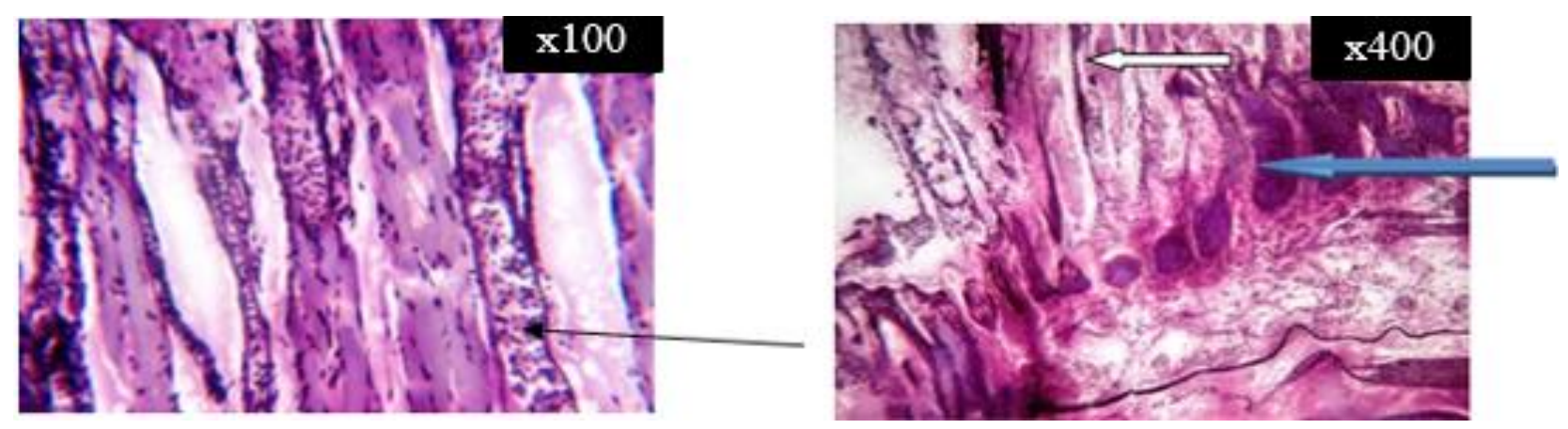

Figure 12. Photomicrograph of group 5 fish gill section 
Histological changes in the muscles of Oreochromis niloticus fed experimental diets

The histopathological examination of the muscles revealed that muscles sections of group 1 showed normal architecture (white arrow), the pathological lesion was not seen (Figure 13), group 2 showed normal architecture (white arrow), with no pathological lesion (Figure 14).

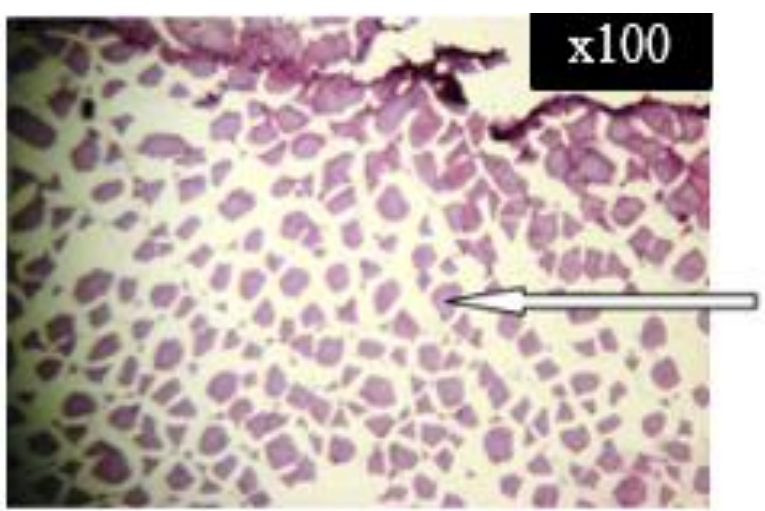

Figure 13. Photomicrograph of group 1 fish muscle section

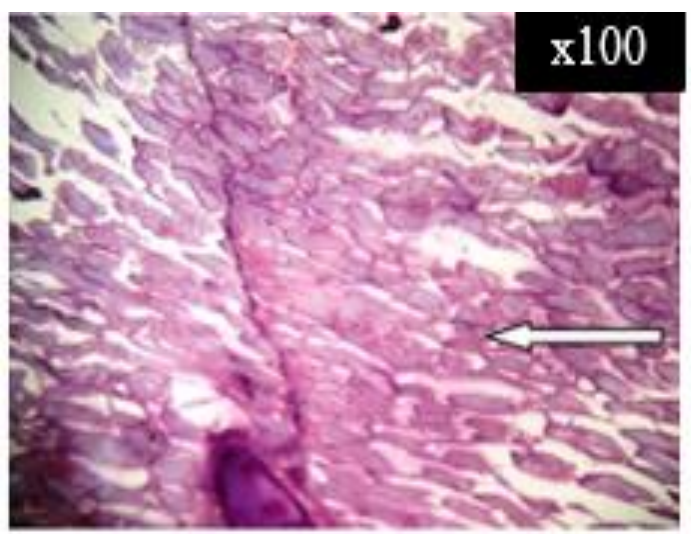

Figure 14.Photomicrograph of group 2 fish muscle section
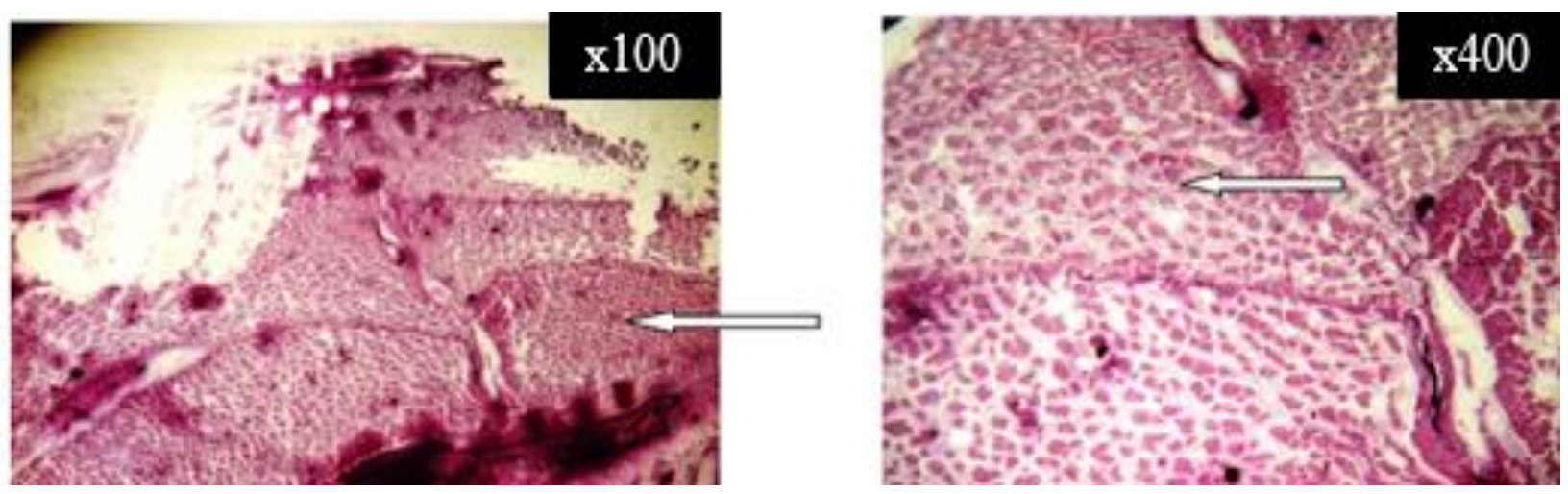

Group 3 showed normal architecture (white arrow), without pathological lesion (Figure 15), while group 4 showed moderate architecture (white arrow), with no pathological lesion found (Figure 16) whereas group 5) (Figure 17) showed a poor architecture, but with the presence of pathological lesion including moderate to severe necrosis (black arrow).
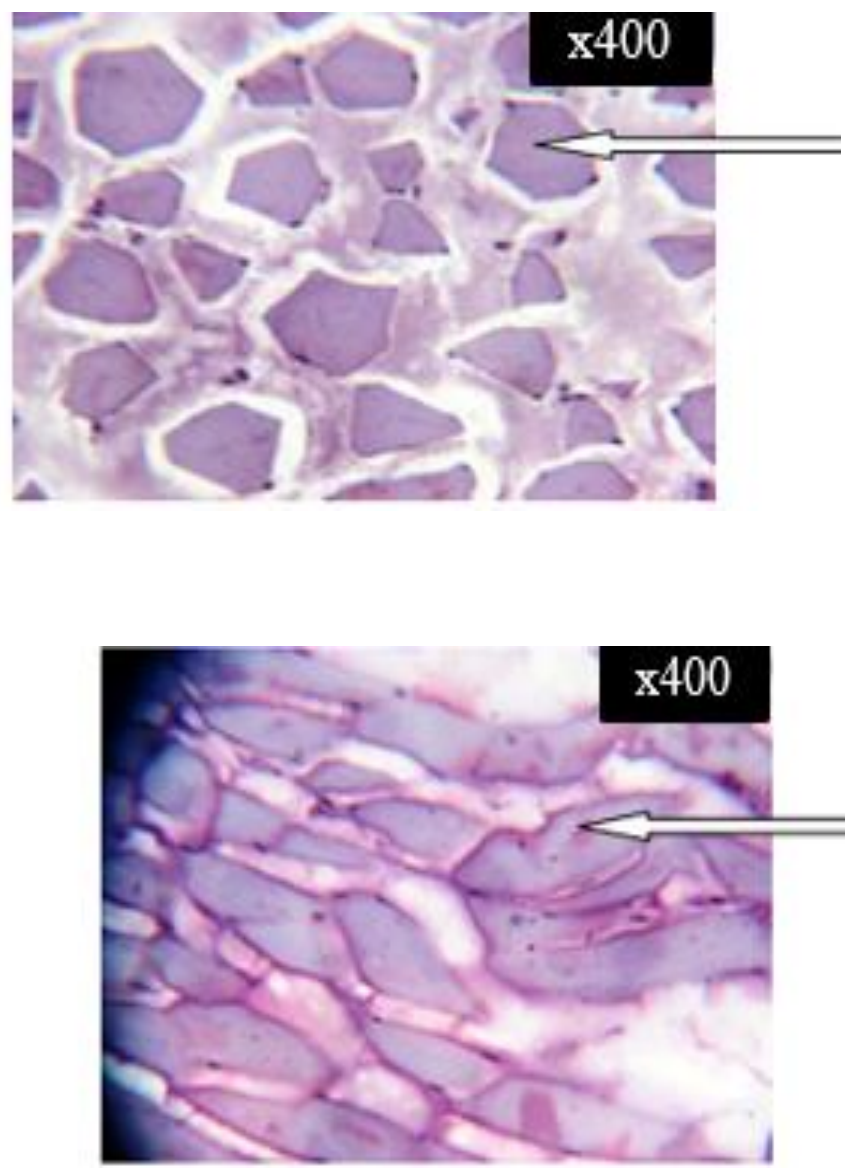

Figure 15.Photomicrograph of group 3 fish muscle section 


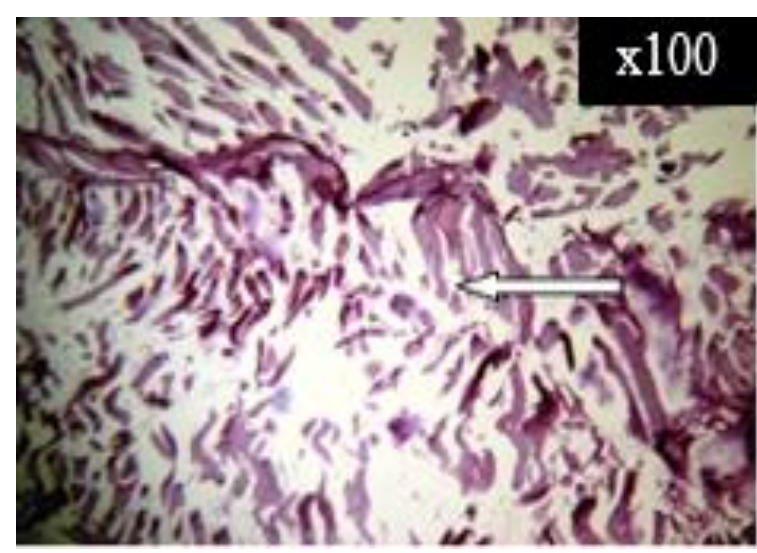

Figure 16.Photomicrograph of group 4 fish muscle section

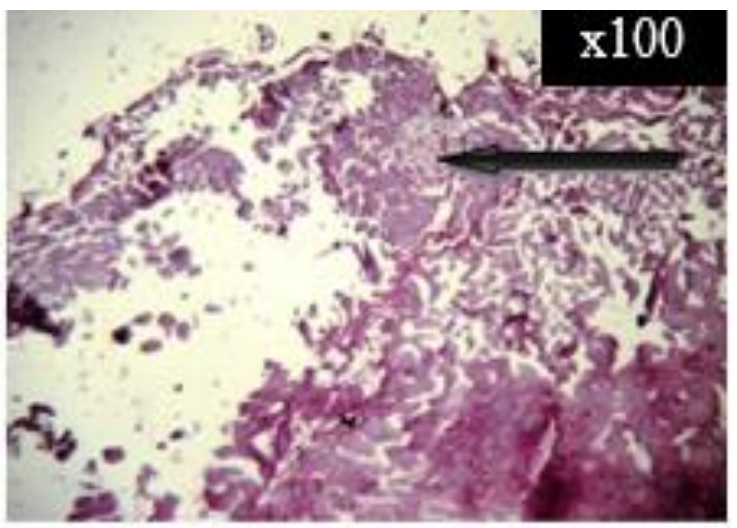

Figure 17.Photomicrograph of group 17 fish muscle section

\section{DISCUSSION}

The examination of external genital papillae of 0 . niloticus showed that the natural hormone and plant extract had the highest male percentage. However, MT treated diet had the highest indistinct percentage rate and mortality rate. These results are in line with the findings of Mohamed (2019) that reported the variation between morphological and gonad results. Mohamed (2019) examined 50 fish from a group; morphologically, 40 of the fishes were presumed to be males, but after gonad and histological examination of the gonad, it was observed that there were 42 males, seven females and one hermaphrodite. The result from this study showed that MT had the lowest percentage of phenotypic males (79.26\%). Group 3 had the highest percentage male ratio. The differences among the groups were scientifically significant. The lowest male ratio was observed in the MT diet, this may be due to the high percentage indistinct found in group 1 compared to all other groups upon observation, while groups 3 and 4 had the lowest rate.

Hussain (2004) and Rahma et al. (2015) reported that the sexual dimorphism of tilapia is expressed in genital papillae. Furthermore, at the time of sex determination, few fish were
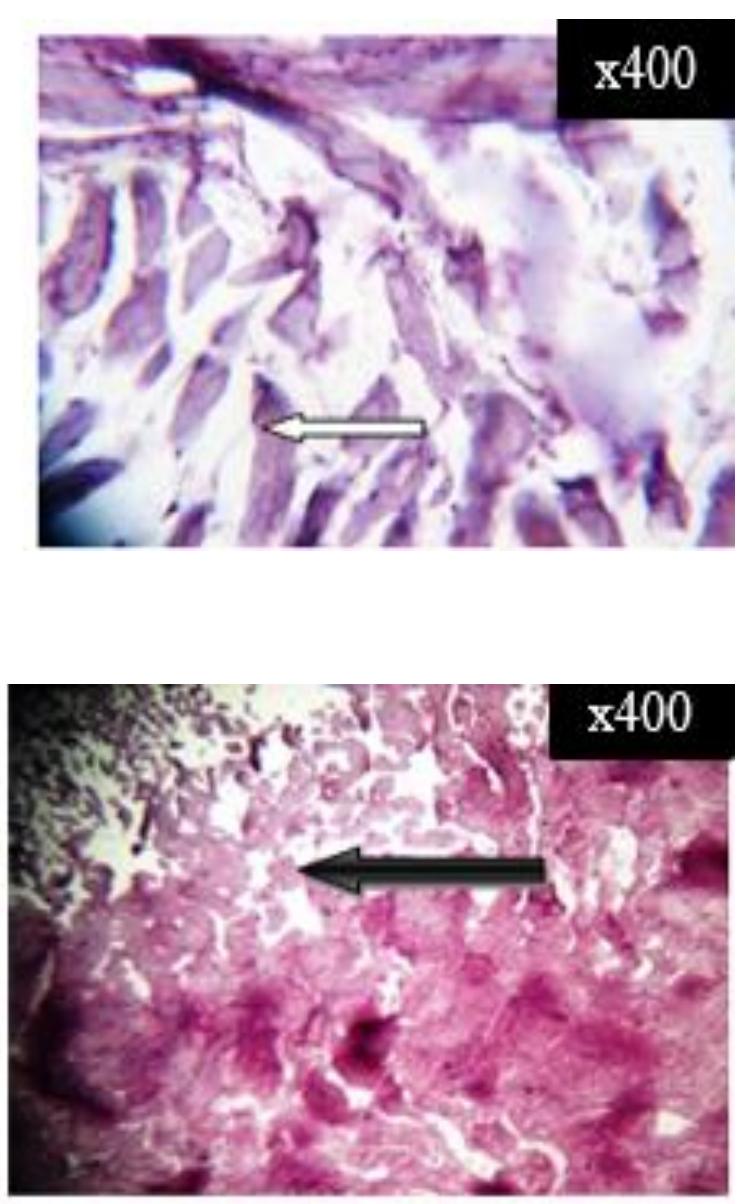

less than $4 \mathrm{~g}$ in weight; at this stage, sex determination of the gonad is difficult. Fish with reduce weight and abnormalities were regarded as indistinct. In this study, fish genital papilla that was not clear at the time of sex determination were regarded as indistinct. In addition, Ekwu and Sikoki (2001), sexed tilapia at $2 \mathrm{~g}$ and observed indistinct fish by gross examination. They reported that those indistinct fish turned out to be female after histological sectioning, which was not in line with Berger and Rothbard (1987) that reported that indistinct fish were regarded as male.

The liver section of the present study (Figure 3-8) showed pathological differences among the groups, mildly congested central vessels that were with mildly thickened vascular wall, although group 2 were normal in the central vessels, however, there was mild perivascular infiltration seen in groups 3 and 4 . Groups 3 and 4 showed normal central vessels that were not congested, on the other hand, group 5 showed mildly congested central vessels, the sinusoids appeared normal and not infiltrated by inflammatory cells. This finding agrees with a similar study by Khater (1998) in studying the effect of different doses $(15,30,60,90 \mathrm{mg})$ of

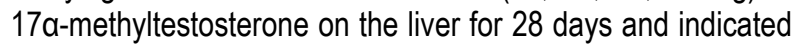
that the hepatic parenchyma had diffused vacuolar 
degeneration while the central veins and hepatic sinusoids were congested, on the contrary, Deborah, (1990) and Kefi et al. (2013) found that there was no deviation from the normal morphology in livers. However, in this study, there appeared to be differences in the hepatocytes, abundant glycogen vacuolation in groups 2 and 4 . But group 1 showed abundant glycogen vacuolation and somewhat fat infiltration, group 3 showed moderate glycogen vacuolation, while group 5 showed abundant glycogen vacuolation with fat degeneration. Khater (1998), also reported that liver tissue treated with 60 mg MT for 14 days showed diffuse hydropic degeneration, congestion of central vein and haemorrhage was seen in the hepatic parenchyma. Furthermore, Dias-Neto et al. 2016 observed that only the larvae that received hormone had hydropic degeneration on day 28 , while the fish fed with and without hormone had more lesions and severe lesions (lipid degeneration).

The liver histological changes in this study were pronounced more in the fish exposed to methyl-testosterone and pawpaw seed basal diet. Although, Myers et al. (1987) reported that alterations are often associated with a degenerative-necrotic condition. Similarly, Gayão et al. (2013) found a high level of protein in fish that received steroid hormone with higher hepatic alterations. Additionally, Sayed et al. (2018) observed hydropic degeneration in the hepatocytes and blood congestion in the central vein of tilapia fish produced using 17alpha-methyltestosterone. In the same vein, diffuse vacuolar degeneration followed by mild and severe vacuolation of the hepatocytes was described by Hasheesh et al. (2011). Furthermore, Suseno et al., 2020 stated that vacuole degeneration was reversible when exposed to toxic substances and at the end of administrating MT; cells could be returned to normal, and congestion was preceded by degeneration of liver cells in which an enlarged vacuole was filled with erythrocytes that cause sinusoid to widen which was accumulated in blood and haemorrhage. Whereas Sipahutar et al. (2013) highlighted that there is no cure for necrosis; if it is exposed to tissue activity continuously, cell activity will decrease, and cells will lose some parts leading to death.

The gill section of the present study (Figure 8-12) showed normal gill lamellae and arch with the lamellae consisting of normal erythrocytes, chloride cells and pillar cells while the gill arch showed normal osteocyte-like cells. This result agrees with the study of Vallada o et al. (2013) that reported severe alterations in gill structure, compromising the function of its filaments. On the other hand, poorly arranged gill lamellae and arch with the lamellae consisting of normal chloride cells and pillar cells, with the gill arch showed normal osteocytelike cells was also observed in this study. Lamellar oedema is the most common lesion in fish and may progress to necrosis of the lamellar epithelium. This can lead to osmoregulatory and respiratory distress, which may result in health compromise, development, and survival of fish (Yang and Albright 1992).

According to the study of Suseno et al. 2020, larger than normal gill lamella looked unclear between the primary and secondary lamellas which is a result of hypertrophy (cell enlargement). Furthermore, Dias-Neto et al. 2016 also reported that Edema of branchial lamellae was less pronounced in the fish fed with natural feed at the end of the experiment.

The histopathological examination of the muscles revealed that muscles sections showed normal, moderate and poor structure throughout the experimental period. In contracts, Khalil et al., 2011 and Curtis et al. (1991) stated that there was no change in muscle composition and traces of hormone accumulation in the muscle tissue of fish. Additionally, the residual value of 17 a- methyltestosterone in Oreochromis niloticus fry muscle dropped significantly after the withdrawal period of 6 weeks but was still higher than their control group (El- Nemr et al., 1999). In this study, we also observed pathological lesions including moderate to severe necrosis.

Pandian and Kirankumar (2008) observed that a high concentration of MT was found in the muscle and flesh; because the MT metabolite has been absorbed into the muscle and flesh of fish, which might cause accumulation every month of this hormone in the flesh. In addition, excretion of methyltestosterone and rapid metabolism by fish treated early with the extended period needed to produce a marketable size fish results in a safe consumer product (Phelps, 2001).

\section{CONCLUSION}

The obtained results in this study showed the superior effects of plant extract, steroid and natural hormone in the sex reversal rates of Oreochromis niloticus. Although, the highest indistinct percentage and mortality rate was recorded in the MT-treated diet while the least was recorded in diets 3 and 4 with no significant difference. Consequently, all groups showed histopathological differences in the livers, gills, and muscles. However, the liver histology of groups 1 and 5 showed central vessels that are mildly congested with abundant glycogen vacuolation and somewhat fat infiltration while muscle histology of group 5 showed pathological lesions including moderate to severe necrosis. These changes can be measured as a sign of fish performance indicating the effects of plant extract and MT. However, further studies are essential for a better understanding of its effects. 


\section{REFERENCES}

Ajiboye, O. O., Okonji, V. A. \& Yakubu, A. F. (2015). Effect of testosteroneinduced sex reversal on the sex ratio, growth enhancement and survival of Nile Tilapia Oreochromis niloticus) fed coppens and farm produced feed in a semi flow-through culture system. Fish Aquaculture Journal, 6(123), 2. DOI: 10.4172/2150-3508.1000123

Avwioro O.G. (2010). Histochemistry and tissue pathology, principle, and techniques. 2nd Edition, Ibadan: Claverianun Press

Berger, A \& Rothbard, S. (1987). Androgen induced sex-reversal of Red Tilapia fry stocked in Cages within Ponds. Bamidgeh, 39(2), 49-57

Curtis, L. R., Diren, F. T., Hurley, M. D., Seimand, W. K. \& Tubb, R. A. (1991). Disposition and elimination of $17 \propto$-testosterone in Nile tilapia (Oreochromis niloticus). Aquaculture, 99, 193-201. DOI: 10.1016/0044-8486(91)90298-L

Dauda, A. B., Yakubu, S. O. \& Oke, A. O. (2014). Curbing the menace of prolific breeding in "aquatic chicken" (Tilapia): A way out to improve fish production in Nigeria. New York Science Journal, 7 (4), 112-118. ISSN: $1554-0200$

Deborah, A. S. (1990). The effects of the synthetic steroid 17-alpha-methyl testosterone on the growth and organ morphology of the channel catfish (Ictalurus punctatus). Aquaculture, 84, 81-93. DOI:10.1016/0044-8486(90)90302-4

Dergal, N. B., Scippo, M. L., Degand, G., Gennotte, V., Mélard, C. \& ElAmine, A. A. S. M. (2016). Monitoring of 17a-methyltestosterone residues in tilapia's (Oreochromis niloticus) flesh and experimental water after its sex reversal. International Journal of Bioscience, 9(6), 101-113. DOI: 10.1016/S0044-8486(02)00276-4

Desprez, D., Geraz, E., Hoareau, M. C., Melard, C., Bosc, P. \& Baroiller, J. F. (2003). Production of a high percentage of male offspring with a natural androgen, 11B hydroxyandrostenedione 11BOHA4), in Florida red tilapia. Aquaculture, 216, 55-65. DOI:10.1016/S0044-8486(02)00276-4

Dias-Neto, J., Valladão, G. M. R., de Oliveira Viadanna, P. H., \& Pilarski, F. (2016). Three strategic feeding during hatchering of Nile tilapia: effects on organs integrity, parasitism, and performance parameters. International Aquatic Research, 8(1), 37-48. DOI: 10.1007/s40071-016-0123-4

Ekwu, A. O. \& Sikoki, F. D. (2001). Comparison of hormonally induced sex direction in two strains of Oreochromis niloticus (Trewavas). Journal of Aquatic Sciences, 16(2), 147-149. DOI: 10.4314/jas.v16i2.20023

El-Greisy, Z. A. \& El-Gamal, A. E. (2012). Monosex production of tilapia, Oreochromis niloticus using different doses of $17 \mathrm{a}$-methyltestosterone with respect to the degree of sex stability after one year of treatment. The Egyptian Journal of Aquatic Research, 38(1), 59-66. DOI: 10.1016/j.ejar.2012.08.005

El-Nemr, I. Z., Haleem, H. H. \& Abdou, K. A. H. (1999). Evaluation of the effect of 17 a-methyltestosterone on monosex, mortality rate and residual values in tilapia (Oreochromis niloticus). Beni- Suef Veterinary Medicine Journal, 9(2), 25-33.

FAO (2010). The State of world fisheries and aquaculture 2010. FAO, Rome, 2010, 197

Fuentes-Silva, C., Soto-Zarazúa, G. M., Torres-Pacheco, I. \& Flores-Rangel, A. (2013). Male tilapia production techniques: a mini-review. African Journal of Biotechnology 12(36); 5496-5502. DOI: 10.5897/AJB11.4119

Gayão, A. L. B. D. A., Buzollo, H., Favero, G. C., Junior, S., Araújo, A., Portella, M. C. \& Carneiro, D. J. (2013). Hepatic histology and cage production of Nile tilapia hormonally masculinized or nonmasculininized. Pesquisa Agropecuária Brasileira, 48(8); 991-997. DOI: $10.1590 /$ S0100-204X2013000800026

Green, B. W., Veverica, K. L. \& Fitzpatrick, M. S. (1997). Chapter 10: Fry and fingerling production: 227-33. In H.S. Egna , C.E. Boyd (Eds.). Dynamics of pond aquaculture. (437 p) USA. CRC Press LLC.

Hasheesh, W. S., Marie, M. A. S., Abbas, H. H., Eshak, M. G. \& Zahran, E. A. (2011). An evaluation of the effect of 17 a-methyl testosterone hormone on some biochemical, molecular, and histological changes in the liver of Nile tilapia; Oreochromis niloticus. Life Science Journal, 8(3), 343-358.
Hulak, M., Paroulek, M., Simek, P., Kocour, M., Gela, D., Rodina, M. \&

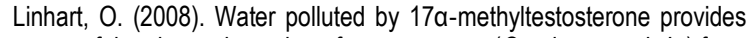
successful male sex inversion of common carp (Cyprinus carpio L.) from gynogenetic offspring. Journal of Applied Ichthyology, 24(6), 707-710. DOI: 10.1111/j.1439-0426.2008.01107.x

Hussain, M. G. (2004). Farming of Tilapia, breeding plans, mass seed production and aquaculture techniques (p. 149). Dhaka: Momin Offset Press.

Jaiswal, P. \& Singh, D. K. (2008). Molluscicidal activity of Carica papaya and Areca catechu against the freshwater snail Lymnaea acuminata. Veterinary Parasitology, 152(3-4), 264-270. DOI: 10.1016/j.vetpar.2007.12.033

Kefi, A. S., Kang'ombe J., Kassam, D. \& Katongo, C. (2013). Effect of 17 amethyl testosterone on haematology and histology of liver and heart of Oreochromis andersonii (Castelnau, 1861). Journal of Marine Science: Research and Development, 3, 130. DOI: 10.4172/2155-9910.1000130

Khalil, W. K., Hasheesh, W. S., Marie, M. A. S., Abbas, H. H., \& Zahran, E. A. (2011). Assessment the impact of 17a-methyltestosterone hormone on growth, hormone concentration, molecular and histopathological changes in muscles and testis of Nile tilapia; Oreochromis niloticus. Life Science Journal, 8(3), 329-343.

Khater, A. M. M. (1998). Sex reversal in Tilapia nilotica. Ph.D. Thesis. Zagazig University, Agricultural Science (Poultry ProductionAquaculture- Fish hatching and sex reversal), $144 \mathrm{p}$.

Megbowon, I. \& Mojekwu, T. O. (2014). Tilapia sex reversal using methyl testosterone (MT) and its Effect on Fish, Man and Environment. Biotechnology, 13(5), 213-216. DOI: 10.3923/biotech.2014.213.216

Mengumphan, K., Samitasiri, Y. \& Carandang, R. (2006). The potential of red kwao kreua (Butea superba) in inducing sex reversal on three strains (Red, Ghana, Chitralada) of Nile tilapia (Oreochromis niloticus L.) and the effect of 17-a- methyltestosterone (MT). Asian fisheries science, 19, 271-279. DOI: 10.33997/j.afs.2006.19.3.007

Meske, C. P. B. \& Vogt, F. (2014). Fish aquaculture: technology and experiments. Federal Research Center for Fisheries, Institute for Coastal and Inland Fisheries.1-5.

Mlalila, N., Mahika, C., Kolombo, M.L., Swai, H. \& Hilanga, A. (2015). Human food safety and Environmental hazards associated with the use of methyltestosterone and steroids in production of all male Tilapia. Environmental Science and Pollution Research, 22(7), 4922-31. DOI: 10.1007/s11356-015-4133-3

Mohamed, H. A. O. (2019). The Use of Sex Hormone in Sex Reversal of Oreochromis niloticus. Journal of Aquatic Science and Marine Biology 2 (1); $1-7$

Myers, M. S., Rhodes, L. D. \& McCain, B. B. (1987). Pathologic anatomy and patterns of occurrence of hepatic neoplasms, putative preneoplastic lesions, and other iodiopathic hepatic conditions in English sole (Parophrys vetulus) from Puget Sound, Washington. Journal of the National Cancer Institute, 78, 333-363. DOI: 10.1093/jnci/78.2.333

Orose, E. \& Vincent-Akpu, I. (2016). Cost-benefit on masculination of Nile Tilapia (Oreochromis niloticus) using natural and artificial hormone. International Journal of Biosciences and Technology, 9(8), 46. ISSN: $0974-3987$

Orose, E., Wokoma, A. \& Woke, G. N. (2016). Sex reversal of Nile Tilapia (Oreochromis niloticus) using 17a-methyl-testosterone, wet testes from selected animals and plant extract. International Journal of Life Science Research, 3(4), 23-29.

Orose, E., Woke, G. N. \& Bekibele, D. O (2018). Growth response and survival of Nile Tilapia (Oreochromis niloticus) using steroid hormone, animal testes, and pawpaw seed-based diet. Nigerian Journal of Fisheries, 15(1), 1336-1341.

Pandian, T. J. \& Kirankumar, S. (2008). Recent advances in hormonal induction of sex-reversal in fish. Journal of Applied Aquaculture, 13(3-4), 205-230. DOI: 10.1300/J028v13n03_02

Phelps, R. P. \& Popma, T. J. (2000). Sex reversal of Tilapia. In B.A. CostaPierce, J. E. Rakocy, (Eds). Tilapia Aquaculture in the Americas 2 (pp. 
34-59). The World Aquaculture Society, Baton Rouge Louisiana, United States.

Phelps, R. P. (2001). Sex reversal: the directed control of gonodal development in tilapia. Pages 35-60. In D.E. Meyer (Ed.). Proceedings for Tilapia Sessions from the 6th Central American Aquaculture Symposium. 22-24 August 2001, Tegucigalpa, Honduras.

Rahma, A., Kamble, M. T., Ataguba, G. A., Chavan, B. R., Rusydi, R., \& Melisa, S. (2015). Steroidogenic and thermal control of sex in tilapia ( $O$. niloticus): A review. International Journal of Current Microbiology and Applied Sciences, 4(1), 214-229.

Rizkalla, E. H., Haleem, H. H., Abdel-Halim, A. M. M. \& Youssef, R. H. (2004). Evaluation of using 17a-methyl testosterone for monosex Oreochromis niloticus fry production. Journal of the Egyptian German Society of Zoology, 43(a), 315-335

Robert, B. M. (2011). Biology of fish. California Animal Health and Food Safety Laboratory System University of California.

Roberts, R. J. \& Ellis, A. E. (1978). The anatomy and physiology of Teleosts. In R.J. Robert (Ed.), Fish Pathology, (4thEdn), Wiley-Blackwell, Oxford, London, UK.

Sayed, A. E. D., Farrag, M., Abdelaty, B., Toutou, M., \& Muhammad, 0. (2018). Histological alterations in some organs of monosex tilapia (Oreochromis niloticus, Linnaeus, 1758) produced using methyltestosterone. Egyptian Journal of Aquatic Biology and Fisheries, 22(4), 141-151. DOI: 10.21608/ejabf.2018.13272
Sipahutar, W. L., Aliza, D. \& Winaruddin, N. (2013). Histopathological of tilapia Oreochromis niloticus gill maintained in heat temperature. Jurnal Medik Veteriner, 7, 19-21.

Suseno, D. N., Luqman, E. M., Lamid, M., Mukti, A. T. \& Suprayudi, M. A. (2020). Residual impact of 17a-methyltestosterone and histopathological changes in sex-reversed Nile tilapia (Oreochromis niloticus). Asian Pacific Journal of Reproduction, 9(1), 37 - 43. DOI: 10.4103/2305-0500.275527

Valladão, G. M. R., Pa'dua, S. B., Gallani, S. U., Menezes-Filho, R. N., DiasNeto, J., Martins, M. L. \& Pilarski, F. (2013) Paratrichodina africana (Ciliophora): a pathogenic gill parasite in farmed Nile tilapia. Veterinary Parasitology, 197(3); 705-710. DOI: 10.1016/j.vetpar.2013.04.043

World Health Organization (2002). WHO Monographs on Selected Medicinal Plants, Volume 2. Geneva: World Health Organization.

Xu, P., Kpundeh, M. D., Qiang, J., \& Gabriel, N. N. (2015). Use of herbal extracts for controlling reproduction in tilapia culture: Trends and Prospects-a Review. Israeli Journal of Aquaculture-Bamidgeh, 67, 20705.

Yang, C. Z. \& Albright, L. J. (1992). Effects of the harmful diatom Chaetoceros concavicornison respiration of rainbow trout Oncorhynchus mykiss. Diseases of Aquatic Organisms, 14(2), 105-114. DOI: 10.1007/s40071-016-0123-4

Zulfahmi, I., Affandi, R. \& Batu, L. T. F. D. (2015). Changes in the structure of gill and liver histology in tilapia fish Oreochromis niloticus Linnaeus, 1758 exposure to mercury. Jurnal Edukasi dan Sains Biologi; 4, 25-31. 